\title{
Kapalı Otobüs Durağı Uygulamalarının Kullanıcı Beklentileri ve Memnuniyeti Doğrultusunda İncelenmesi: Gümüşhane ve Antalya Örneği
}

\author{
Investigation of Enclosed Bus Station Applications in Terms of User Expectations and \\ Satisfaction: Case of Gümüşhane and Antalya Cities
}

\author{
Emine ÇORUH ${ }^{1, a}$, Metin Mutlu AYDIN*2,b, Eren DAĞLI ${ }^{1, \mathrm{c}}$, Ömer Faruk ÖZTÜRK ${ }^{3, d}$, Mehmet Sinan \\ YILDIRIM $^{4, \mathbf{e}}$ \\ ${ }^{1}$ Gümüşhane Üniversitesi, Mühendislik ve Doğa Bilimleri Fakültesi, İnşaat Mühendisliği Bölümü, 29100, Gümüşhane \\ ${ }^{2}$ Ondokuz Mayıs Üniversitesi, Mühendislik Fakültesi, İnşaat Mühendisliği Bölümü, 55270, Samsun \\ ${ }^{3}$ Giresun Üniversitesi, Tirebolu Mehmet Bayrak Meslek Yüksek Okulu, Ulaştırma Hizmetleri Bölümü, 28500, Giresun \\ ${ }^{4}$ Manisa Celal Bayar Üniversitesi, Mühendislik Fakültesi, İnşaat Mühendisliği Bölümü, 45110, Manisa
}

\begin{abstract}
• Geliş tarihi / Received: 09.03.2020 • Düzeltilerek geliş tarihi / Received in revised form: 26.06.2020 • Kabul tarihi / Accepted: 10.09.2020
\end{abstract}
Öz

Son yıllarda otobüs ve minibüs duraklarının kalitesini arttırmak amacıyla tamamen kapalı, dijital ya da görsel bilgilendirme vb. birçok özelliğe sahip kapalı durak tasarımları uygulanmaktadır. Fakat bu kapalı durakların özellikleri, benzer karakteristik özelliklere sahip kentlerde benzer ihtiyaç ve kullanıcı beklentilerine sahip olabilmektedir. Bu yüzden ülke genelinde benzer karakteristik özelliklere sahip kentler için ortak bir kapalı durak tipi belirleyerek onu ihtiyaç olan şehirlerde uygulamak, durakların kalitesi konusunda bir iyileşme sağlayabilecektir. Bu kapsamda bu tür ortak özelliklere sahip şehirler için tasarlanacak duraklarda kullanıcıların beklentilerinin önceden belirlenmesi, durakların işlevselliğine önemli katkı sağlayabilecektir. Bu amaçla çalışmada kapalı durak tasarımı için kullanıcıların özellikle farklı hava koşullarına sahip büyük/küçük ölçekli şehirlerdeki mevcut kapalı duraklardan memnuniyeti ile bu duraklarda olmasını istedikleri özellikler bir anket çalışması ile incelenerek ortak bir durak yapısı önerilmeye çalışılmıştır. Analizler kapsamında hazırlanan anket soruları, yüz yüze yapılan anketlerden elde edilen sonuçlara göre faktör analizi ile alt gruplara ayrılmıştır. Sonrasında ise durak kullanıcıları ve bunların duraklardan memnuniyetleri arasındaki ilişki Sıralı Logit Regresyon (SLR) analizi ile incelenmiştir. Elde edilen sonuçlara göre kapalı durak kullanıcılarının yaşadığı şehrin, meslek grubunun memur ve öğrenci olmasının, durakta bekleyen kişi sayısının ve durakta bekleme süresinin 10 ' dk ve daha fazla olmasının durak memnuniyeti üzerinde istatistiksel olarak anlamlı değişkenler olduğu belirlenmiştir. Yine sonuçlardan kapalı durak kullanıcıları, mevcut duraklardan memnun gibi görünse de bu tür duraklarda olmasını bekledikleri bazı farklı ve önemli özelliklerin olduğu görülmüştür.

Anahtar kelimeler: Kapalı Otobüs Durağı, Kullanıcı Beklentileri, Otobüs Durak Kullanımı, Tasarım Konsepti, Toplu Taşıma

\begin{abstract}
In recent years, to increase the quality of bus and minibus stations, fully enclosed station designs with many features such as digital or visual information etc. are implemented. However, features of these stations, may have similar needs and user expectations in cities with similar characteristics. Therefore, applying enclosed stations, by determining a common enclosed station for similar cities in all over the country, will provide an improvement in the quality. For this scope, pre-determining the expectations of the users in the stations for similar cities with such common features can make a significant contribution to the functionality. For this aim, in the study, user satisfactions from the stations in large and small-scale cities with different weather conditions were investigated and the features of the stations were determined by cunducting face to face surveys. Survey questions were prepared by dividing questions into sub-groups with factor analysis according to obtained results from the surveys. Subsequently, station users and the relationship between their satisfactions from the stations were examined with Ordinal Logistic Regression (OLR). According to results, it was determined that the cities where the passenger use enclosed station live in, user occupation (student or public staff), the number of people waiting at the station and the waiting time at station for 10 minutes or more were statistically significant variables on satisfaction. It was aslo seen from the results, even though the passengers of the enclosed stations seem to be satisfied from the current stations, users still wait some different and important features.
\end{abstract}

Keywords: Enclosed Bus Station, User Expectations, Bus Station Utilization, Design Concept, Public Transportation

\footnotetext{
*1b Metin Mutlu AYDIN; metinmutluaydin@gmail.com, Tel: (0506) 26991 49, orcid.org/0000-0001-9470-716X

${ }^{\mathrm{a}}$ orcid.org/0000-0002-3251-9179 $\quad{ }^{\mathrm{c}}$ orcid.org/ 0000-0002-3892-0270 $\quad{ }^{\mathrm{d}}$ orcid.org/0000-0002-7397-4274

'orcid.org/0000-0001-5347-2456
} 


\section{Giriş}

Ulaştırma sistemleri; insan ve yük/eşyanın belirli bir amaç için bir yerden başka bir yere hareketinin, istenilen koşullarda, belirli ve iyi tanımlanmış bir şekilde hizmet vermesini sağlamak için işlevleri ve karşılıklı etkileşimleri, organize edilen ilgili tüm fiziksel, sosyal, ekonomik ve kurumsal bileşenlerin kümesidir (Yaşar, 2009; Murat ve Çakici, 2017). Dünya çok hızlı bir şekilde kentleşirken, şehirlerde kalkınma ve hareketlilik (ulaşım hareketliliği) kalıpları açısından büyük bir değişim gözlenmektedir (Hickman vd., 2010). Yapılan tahminlere göre şu andaki büyüme hızı ile dünya nüfusunun \%66'sının 2050 yılında kentlerde olacağ 1 tahmin edilmektedir (URL-1, 2019). Türkiye'de ise 1927 y1lında nüfusun $\% 75.8$ 'i kırsal alanlarda ve sadece $\% 24.2$ 'si kentsel alanlarda yaşarken, bugün bu durum tam tersine dönmüş ve 81 milyonluk ülkemizde ciddi bir değişimle \%92.1 oranında insan kentlerde yaşamakta ve ulaşım hareketliliği göstermektedir (TÜIK, 2018). Günümüzde, dünya genelindeki nüfusun büyük bir çoğunluğu şehirlerde yaşamakta ve şehirlerde artan nüfus, insanların iş, gezi vb. çeşitli sebepler ya da ihtiyaçlar nedeniyle sürekli hareket halinde bulunmasına neden olmaktadır. Ulaşımın büyüklüğünü belirtmek için, "hareketlilik" kavramı ile ifade edilen bir ölçü birimi kullanılmaktadır ve "hareketlilik", bir taşıt veya bir yaya için belirlenen günlük ortalama yolculuk sayısı olarak tanımlanmaktadır (Akbaş ve Akdoğan, 2001). Bireysel araç kullanılmadan yapılan yolculuklarda, kullanılan bütün ulaştırma sistemleri genel olarak toplu taşıma olarak tanımlanmaktadır (Kim vd., 2009). Bilimsel olarak ise toplu taşıma, belirli ve sabit bir güzergâhı olan, fiyatı bilinen, zaman tarifesi olan, isteyen herkesin yararlanabileceği, kent içi yolcu taşımacılığında kullanılan sistemlerin genel adı olmaktadır (Ilıcalı vd., 2011).

Günümüzde kentsel ulaşımda bisiklet, otomobil, otobüs, tramvay vb. birçok farklı ulaşım türü mevcuttur (Tekin vd., 2018). Öyle ki toplu taşımanın daha da özendirilmesi amacıyla bisiklet paylaşımı, araç paylaşımı gibi birçok yeni türde ortaya çıkmış olup yaygın şekilde kullanılmaktadır (Aydın ve Yıldırım, 2019; Saplıoğlu ve Aydın, 2018). Her ne kadar farklı birçok ulaşım türü olsa da otobüs ile toplu taşıma halen birçok ülkede en çok kullanılan ulaşım türüdür. Otobüs ile toplu taşıma uygulamalarının yaygınlaşması ve efektif kullanımı üzerindeki en önemli etkenlerden birisi de şüphesiz otobüs duraklarıdır. Otobüs durakları, kentiçi toplu taşımada erişilebilirlik açısından kent yaşamı, planlı ve sürdürülebilir ulaşım için son derece önemlidir. Ayrıca bu durakların düzenlenmesi; otobüs güzergâhlarının, dolayısı ile otobüs hatlarının kullanılabilirliği ve konforu için de önemli bir bileșendir. Otobüs durağını sadece bir indi-bindi noktası olarak görmek ulaşım açısından eksik veya yetersiz bir planlamaya yol açmaktadır. Durakların; toplu taşıma yolcusunun, yaya profilinden yolcu profiline geçtiği, belli bir zaman geçirdiği, gerekli ise, tür-içi veya türler arası aktarma yaptığı bir yer olarak ele alınması gerekmektedir. Dolayısı ile otobüs durakları indibindi hareketine ek olarak bekleme, otobüs tarifesi konusunda ve kent bilgi sistemi destekli kentsel mekân ve aktiviteleri kullanma konusunda bilgilenme ve bunlarla ilişkili bazı gereksinimlerin karşılandığ1 bir ulaşım mekânı olarak tanımlanabilmektedir (Kaplan, 2010). Yol üzeri durak noktalarının oluşturulması gerek kaldırımı kullanan yayalar, gerek bineceği otobüsü bekleyen yolcular gerekse de trafikte bir otobüs arkasında ilerlemekte olan trafik akımı açısından büyük bir öneme sahiptir. Bunun yanı sıra otobüs durak yerlerinin, trafik ana kontrol noktaları olarak değerlendirilebilecek sinyalize kavşaklar açısından da oldukça önemli etkiler yarattığı dikkate alınmalıdır (Nehir, 2009).

Mevcut çalışmalar detaylı olarak incelendiğinde araştırmacıların, toplu taşıma plancı ve işletmecilerinin daha çok kullanıcıların toplu taşıma sistemlerinin performansı üzerine araştırmalar yaptıkları gözlemlenmektedir (Weng vd., 2018; Shaaban vd., 2013; Wojude ve Badiora, 2017; Eboli ve Mazzula, 2009; Bordagaray vd., 2014). Bu kapsamda bazı araştırmacılar toplu taşıma performans indeksi geliştirerek, sistemlerin performansını etkileyen parametreleri araştırmışlardır (Ona vd., 2016; Bordagaray vd., 2014). Tyrinopoulos ve Antoniou (2008) yaptıkları çalışma ile Yunanistan'ın iki büyük şehri olan Atina ve Selanik'te kullanıcıların toplu taşıma sistemlerinden memnuniyet seviyelerini araştırmışlardır. Beş farklı toplu taşıma şirketinin işlettiği üç farklı ulaşım modu (otobüs, troleybüs, ve metro) üzerinde yapilan memnuniyet araştırmalarına göre kullanıcıların en çok servis sıklığı, bekleme süresi, erişilebilirlik ve araçların temizliğine memnuniyet açısından oldukça büyük önem verdikleri belirlenmiştir. Bir başka çalışmada ise Ali (2010), şehirlerdeki otobüs ile yapılan toplu taşımaya ait performansların şehirlerdeki farklı bölgelere değişiklik gösterdiğini gözlemlemiştir. Çalışma sonuçlarına göre, şehirlerdeki farklı bölgelerde bekleme süresindeki değişiklikler ve otobüs servis 
sıklıklarının değişiklik göstermesinin performans üzerinde etkili olan önemli değişkenler olduğunu belirlemişlerdir. Kamaruddin vd. (2012) ise çalışmasında, yolcuların toplu taşıma sistemlerinden en önemli beklentilerini incelemiş güvenlik, erişebilirdik, uygun ücret, iletişim ve yolculuk konforunun Malezya'daki kullanıcilar için toplu taşıma performansında beklenilen en önemli parametreler olduğu sonucuna ulaşılmıştır. Bir başka çalışmada ise Ali (2014), Abuja/Nijerya şehri özelinde yolcuların toplu taşıma sistemleri üzerindeki performans değerlendirmelerini araştırmıştır. Analiz sonuçlarına göre, dört önemli faktörün memnuniyet üzerindeki en önemli etkenler olduğu belirlenmiştir. Bunlar sırasıyla konfor, erişebilirlik, otobüs durak olanakları (efektif durak tasarımı) ve gelen otobüslerin kapasitesinin yeterli olması olarak belirlenmiştir. Benzer bir diğer çalışmada ise Fellesson ve Friman (2008), dokuz farklı Avrupa şehrinde kullanıcıların toplu taşıma sistemlerinin performans1 hakkındaki memnuniyetlerini değerlendirmiştir. Elde edilen bulgulara göre sistemde çalışan toplu taşıma araçlarının duraklara zamanında gelmesi, servis sıklığı (frekansı) ve araçların geliş zamanları hakkında yeterli bilginin kullanıcılara doğru olarak verilmesi, otobüs durak tasarımı ve güvenliğin memnuniyet üzerindeki önemli parametreler olduğu belirlenmiştir. Murat ve Demirkollu (2017) otobüs ile günlük toplu taşıma yolculuklarında ideal sefer sıklığını hedef programlama yöntemi ile belirleyerek, ideal sefer sıklığının toplu taşıma performansı üzerine etkisine dikkat çekmişlerdir. Yine benzer bir çalışmada ise Murat vd. (2014) bulanık optimizasyon ve doğrusal hedef programlama yaklaşımları ile şehiriçi otobüs duraklarının yeri ve sefer sıklığı arasındaki ilişkiyi inceleyerek optimum tasarımı belirlemişlerdir. Böylece sefer sıklığı ve otobüs duraklarını arasındaki ilişkiye göre en iyileme yaparak toplu taşıma performansını arttırmayı hedeflemişlerdir.

Mevcut literatürden de görüldüğü üzere yapılan çalışmalar daha çok toplu taşıma sistemlerindeki sorunların tespiti ve sistemi en iyileme üzerine olmaktadır. Halbuki yapılan bazı araştırmalarda da dikkat çekildiği üzere otobüs duraklarının doğru tasarımı kullanıcı memnuniyeti üzerindeki en önemli parametrelerden birisidir. Bu amaçla son yıllarda ülkemizde birçok şehirde tüm toplu taşıma türlerini, küçük ölçekli şehirlerde ise otobüs ile ulaşımı daha da yaygınlaştırmak amaciyla toplu taşıma araçları ve durak kalitesini arttırmaya büyük önem verilmektedir. Birçok şehirde yaygın olarak kullanılan toplu taşıma araçlarından olan otobüs ve minibüs duraklarının kalitesini arttırmak amaciyla özellikle tamamen kapalı, 1sıtma/soğutma özelliği olan, dijital ya da görsel bilgilendirme vb. daha birçok özelliğe sahip kapalı durak tasarımları yapılmakta ve uygulanmaktadır. Fakat toplu taşıma sistemlerinin önemli bir parçası olan bu kapalı durakların tasarım özellikleri, inşa edildiği şehrin belirleyici özelliklerine (hava koşulları, kullanıcı yapı, vb.) ve kullanıcıların beklentilerine göre değişiklik gösterebilmektedir. $\mathrm{Bu}$ yüzden benzer karakteristik özelliklere ve kullanıcı beklentilerine sahip şehirlerde tek bir kapalı durak tipi belirleyerek onu tüm şehirlerde uygulamak amaciyla ortak bir kapalı durak kavramının oluşturulması tüm şehirlerde durakların kalitesi konusunda bir birlikteliği sağlayabilmek açısından oldukça önemlidir ve tüm şehirlerdeki kullanıcılara aynı kalitede hizmet verebilmek için gereklidir.

$\mathrm{Bu}$ amaçla çalışma kapsamında bir örnek olarak kullanıcıların özellikle farklı hava koşullarına sahip büyük ve küçük ölçekli şehirlerdeki mevcut kapalı duraklardan memnuniyeti ile kapalı duraklardan olmasını istediği beklentiler incelenerek, sistemin önemli bir bileşeni olan durakların kullanıcı beklentileri doğrultusunda etkinliğinin arttırılması hedeflenmiştir. $\mathrm{Bu}$ kapsamda büyük ölçekli pilot şehir olarak Antalya, küçük ölçekli pilot şehir olaraksa Gümüşhane il merkezleri seçilmiş ve buradaki otobüs duraklarından saha gözlemleri ve yüz yüze yapilan anketler ile veriler elde edilerek analiz edilmiştir. Elde edilen analiz sonuçları ile incelenen pilot şehirlerdeki kapalı durak kullanıcılarının, mevcut duraklar hakkındaki düşünce ve beklentileri sayısal olarak incelenerek kullanıcı beklentilerini karşılayacak kapalı durak önerileri geliştirilmeye çalışılmıştır. Elde edilen sonuçlara göre bu tür şehirlerdeki kapalı duraklarda, kullanıcı beklentileri doğrultusunda olması gereken yapısal özellikler belirlenmiş ve yetkililere bu konuda yol gösterilmeye çalışılmıştır. Böylece hem literatürde hem uygulama da bu konudaki eksik giderilmeye çalışılmıştır.

\section{Materyal ve Metot}

\subsection{Pilot Kentlerin Seçilmesi ve Verilerin Toplanmast}

Çalışma kapsamında verilerin toplanması amacıyla kış aylarında oldukça soğuk kentlere örnek olarak pilot kent olarak Gümüşhane il merkezi ve yaz aylarında sicak kentlere örnek olarak ise oldukça sıcak bir kent olan Antalya il 
merkezi seçilmiştir (Şekil 1). Gümüşhane il merkezi toplu taşıma türü olarak otobüslerin kullanıldığı ve dolayısıyla da açık ve özellikle kapalı otobüs duraklarının yaygın olarak bulunduğu bir şehirdir. Benzer şekilde Antalya'da toplu taşıma da otobüs kullanımının oldukça yaygın olduğu özellikle yaz aylarında otobüs beklerken gölge ve serin bir yer ihtiyacının ön plana çıktığı bir şehirdir. Her iki şehrin ortak özelliğe toplu taşıma sisteminde otobüs ve dolayısıyla durak kullanımının oldukça yoğun olması ve farklı mevsimlerde de olsa kapalı otobüs duraklarının kullanımının şart olmasıdır.

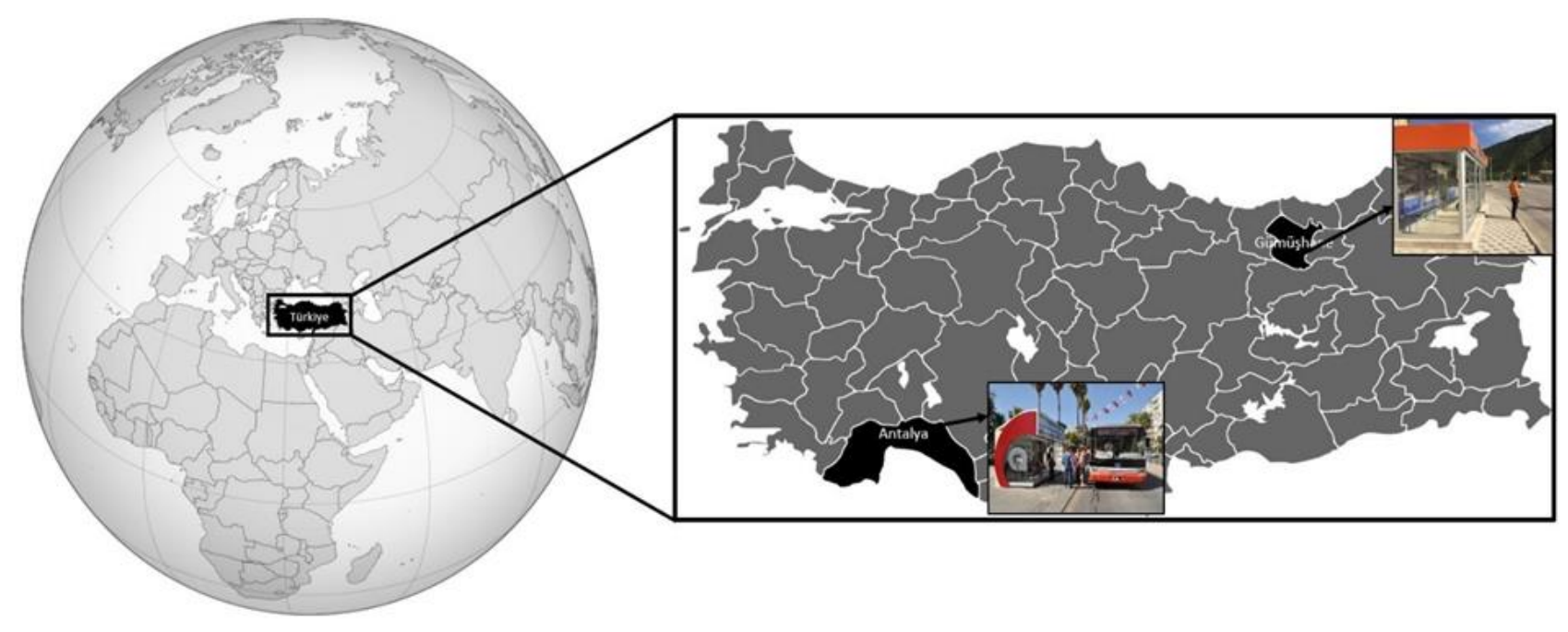

Şekil 1. Çalışma kapsamında seçilen iki farklı pilot kentin harita üzerindeki konumları

Çalışma kapsamında ilk olarak her iki şehirdeki açık ve kapalı otobüs durakları incelenmiştir. Yapılan incelemelerden açık durakların ya sadece bir levhadan ya da üstü, bir yanı veya arkasının kısmen kapalı olduğu bir tasarımdan oluştuğu belirlenmiştir. Yine incelemelerden her iki şehirdeki açık durak tasarımlarının geometrik ve belirleyici özelliklerinin birbirine oldukça benzediği görülmüştür. Yapılan bu gözlemler sonucu elde edilen bilgilere göre açık durak tasarımı konusunda ülkemizde, kullanımı yaygın bir tasarımın var olmasının etkili olduğu söylenebilmektedir. Her iki şehirdeki kapalı duraklar incelendiğinde ise her ne kadar aynı amaç için inşa edilmiş olsalar da geometrik ve belirleyici özelliklerinin birbirinden farklı olduğu belirlenmiş ve bu durum çalışmanın amacını daha da ön plana çıkarmıştır. Yapılan saha incelemelerinden, Antalya il merkezindeki kapalı otobüs duraklarını genel olarak $9.4 \mathrm{~m}^{2}$ alana sahip olduğu ve yolcu hareketliliğinin fazla ya da az olduğu duraklarda bu alanının değişiklik gösterdiği tespit edilmiştir. Kapalı durak sayısı sürekli olarak değişkenlik gösterdiği için bu çalışma içerisinde net bir sayı verilmemiştir. Antalya'daki kapalı duraklarda; genel olarak üç adet ikişerli koltukların (genellikle 8 kişilik), durak içerisinde yolcuların cep telefonlarını şarj edebilmeleri için 220 volt prizlerin, dijital bilgilendirme sistemlerinin, kışın ısıtma ve yazın ise soğutma için klima sistemlerinin bulunduğu fakat bu havalandırma sistemlerinin verimli çalışmadıkları gözlemlenmiştir. Ayrıca tüm kapalı duraklarda o duraktan geçen tüm otobüs hatlarının numaraları ve güzergâhlarına ait bilgilerin olduğu görsellerin olduğu belirlenmiştir. Antalya'daki kapalı otobüs duraklarına ait örnek görseller Şekil 2'de verilmiştir.

Benzer şekilde Gümüşhane il merkezindeki kapalı duraklar incelendiğinde ise kapalı otobüs durakların $7.5 \mathrm{~m}^{2}$ ve $12.6 \mathrm{~m}^{2}$ alana sahip oldukları ve yolcu hareketliliğinin fazla olduğu duraklara göre büyük ya da küçük alana sahip durak uygulamasının olduğu görülmüştür (Şekil 3). Küçük alana sahip duraklarda ise genel olarak iki adet üçerli veya dörderli (6-8 kişilik) ya da bütünleşik şekilde 10 kişilik koltukların, kışın 1sıtma için havalandırma sistemlerinin mevcut olduğu ve bunlarında Antalya'da olduğu gibi ne yazık ki verimli çalışmadıkları gözlemlenmiştir. Durak içerisinde Antalya'daki durumun aksine şehirde farklı yöne giden otobüs hatları olmadığ 1 için Antalya'daki gibi otobüs hatlarının numaraları ve güzergâhlarına ait bilgiler yerine reklam panoları bulunmaktadır.

Çalışma kapsamında veriler, kullanıcıların kapalı duraklardan beklentilerini ve mevcut duraklar hakkındaki memnuniyetlerini, kullanıcıların belirleyici özelliklerine göre her iki şehirde kapalı otobüs duraklarını kullanan yolcularla yüz yüze yapılan anketler sonucu elde edilmiştir. 

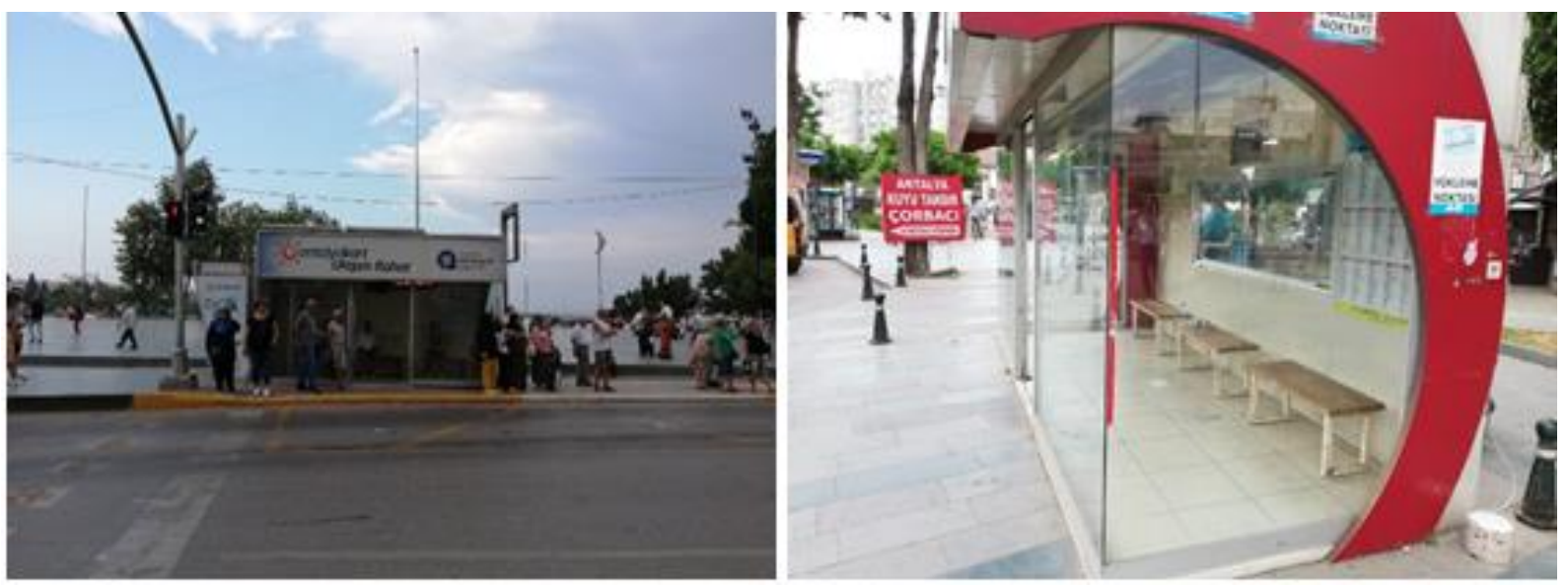

Şekil 2. Antalya kent merkezinde bulunan kapalı duraklara ait örnek görseller
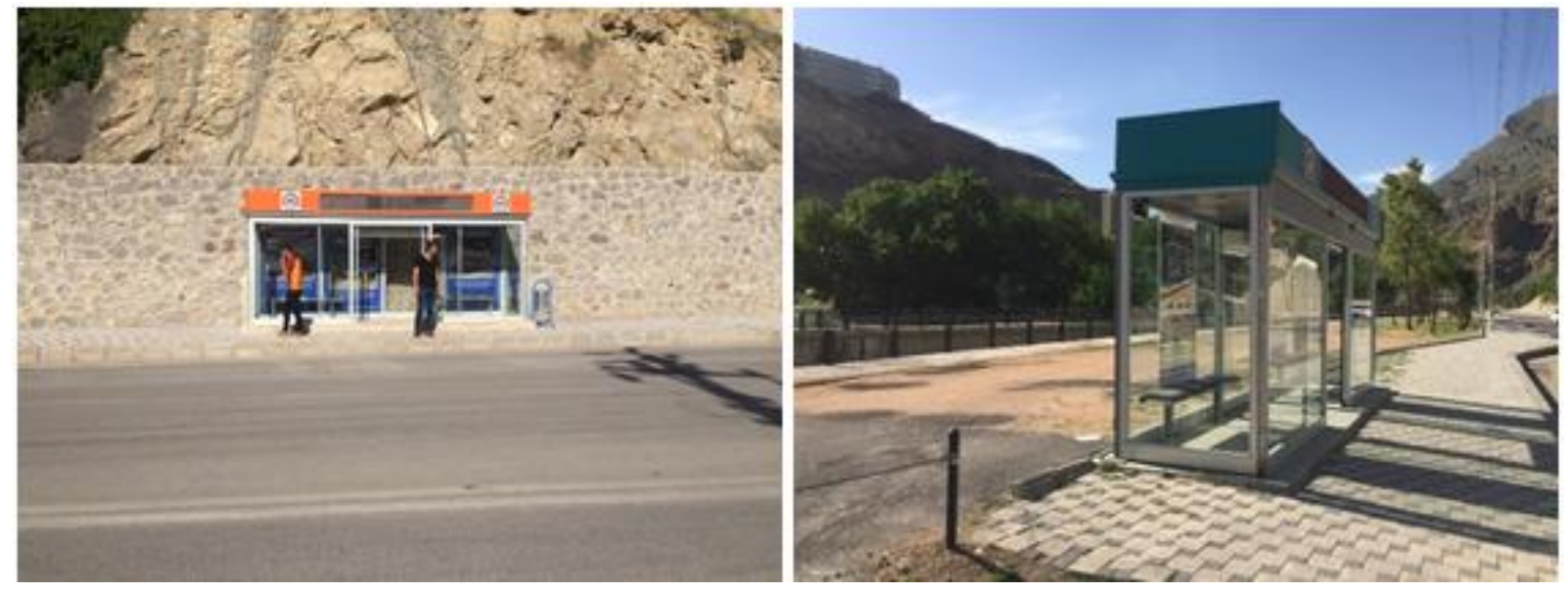

Şekil 3. Gümüşhane kent merkezinde bulunan kapalı duraklara ait örnek görseller

Anketler iki bölüm olarak hazırlanmış olup ilk bölümde kullanıcıların belirleyici özelliklerinin ve durak kullanımı hakkındaki bazı bilgilerin elde edilmesi amaçlanmıştır. İkinci bölümde ise kullanıcılara 22 sorudan oluşan ve 5'li likert ölçeği ile elde edilen değişkenler kullanılarak (1.Kesinlikle Katılmıyorum, 2. Kat1lmiyorum, 3. Kararsızım, 4. Katıliyorum, 5. Kesinlikle Katılıyorum) bir anket uygulanmış ve kapalı durak kullanıcılarının mevcut duraklar hakkındaki düşünce ve beklentilerini ölçmek amaçlanmıştır. Çalışma kapsamında incelenen şehirlerde toplam kapalı durak kullanıcı sayısı bilinmediği için örneklem sayıları (evrendeki eleman sayısı bilinmiyor) Denklem 1 yardımıyla belirlenmiştir.

$n=\frac{t^{2} \times p \times q}{d^{2}}$

Burada;

$n$ : Örnekleme alınacak birey sayısı

t: Belirli serbestlik derecesinde ve saptanan yanılma düzeyinde $\mathrm{t}$ Çizelgesinde bulunan teorik değer $(\alpha=0.05$ ve $\infty$ serbestlik derecesi için 1.96 'dir) p: İncelenen olayıı görülüşs s1klığı (olasıllığ1)

q: İncelenen olayın görülmeyiş sıklığ (olasılığı)

$\mathrm{d}^{2}$ : Olayın görülüşs sıklığına göre yapılmak istenen + sapma

Çalışma kapsamında her iki şehirdeki duraklarda kullanıcı sayısının oldukça fazla olması nedeniyle durak kullanım oranının değişkenliği net olarak bilinmemektedir. $\mathrm{Bu}$ nedenle tahmin yaparken yanlılı̆̆ 1 önlemek için $\mathrm{p}=0.5$ (maksimum değişkenlik) değeri olasılık değeri olarak kullanılmıştır (Saplıoğlu ve Aydın, 2018). Denklem 1 yardımıyla yapılan örnekleme hesabından her iki şehir için minimum değer olarak 385 kişi belirlenmiştir.

$\mathrm{n}=\frac{1.96^{2} \times 0.5 \times 0.05}{0.05^{2}}=385$

Çalışmada Antalya'dan 590 kişi, Gümüşhane'den ise 404 kişi ile farklı duraklarda yüz yüze anket yapılarak; durak kullanıcılarının belirleyici ve durak kullanım özelliklerine bağlı olarak her iki şehirden veriler toplanmıştır. 


\section{Bulgular}

\subsection{Tamamlayıcı Sonuçlar}

Çalışma kapsamında yüz yüze yapılan anketler ile Antalya'dan 590, Gümüşhane'den ise 404 kişiye ulaşılarak toplam 994 kişiye ait anket verisi toplanmıştır. Yapılan analizlerden ankete katılan durak kullanıcılarının yaş ortalaması $26.9 \pm 10.5$ olarak hesaplanmıştır. Yapılan anketlerde kapalı durak kullanıcılarının genel yaş perspektifini yansitabilmek amaciyla minimum 11 yaş, maksimum 73 yaş aralığında farklı yaşlara sahip ve farklı cinsiyetteki kullanıcılara ulaşı1mıştır. Verilerin analizi ile elde edilen bazı istatistiksel sonuçlar Tablo 1'de detaylı olarak verilmiştir.

Tablo 1. Ankete katılan durak kullanıcılara ait bazı özet istatistiksel bilgiler

\begin{tabular}{|c|c|c|c|}
\hline Değişken Adı & Türü & Örneklem Boyutu & Yüzde (\%) \\
\hline \multirow{2}{*}{ Cinsiyet } & Kadın & 406 & 40.8 \\
\hline & Erkek & 588 & 59.2 \\
\hline \multirow{5}{*}{ Meslek } & İşçi & 157 & 15.8 \\
\hline & Memur & 151 & 15.2 \\
\hline & Öğrenci & 595 & 59.9 \\
\hline & Serbest Meslek & 51 & 5.1 \\
\hline & Çalışmıyor & 40 & 4.0 \\
\hline \multirow{6}{*}{ Eğitim Durumu } & İlköğretim & 67 & 6.8 \\
\hline & Lise & 414 & 41.6 \\
\hline & Önlisans & 124 & 12.4 \\
\hline & Lisans & 368 & 37.1 \\
\hline & Yüksek Lisans & 14 & 1.4 \\
\hline & Doktora & 7 & 0.6 \\
\hline \multirow{6}{*}{ Aylık Gelir } & $0-1000 \mathrm{TL}$ & 470 & 47.3 \\
\hline & $1000-2000 \mathrm{TL}$ & 186 & 18.7 \\
\hline & 2000-3000 TL & 151 & 15.2 \\
\hline & $3000-4000 \mathrm{TL}$ & 68 & 6.9 \\
\hline & $4000-5000 \mathrm{TL}$ & 77 & 7.7 \\
\hline & 5000 TL ve Üzeri & 42 & 4.1 \\
\hline \multirow{2}{*}{ Ehliyet Sahipliği } & Var & 562 & 56.5 \\
\hline & Yok & 432 & 43.5 \\
\hline \multirow{2}{*}{ Araç Sahipliği } & Var & 205 & 20.6 \\
\hline & Yok & 789 & 79.3 \\
\hline \multirow{4}{*}{ Durağa Erişim Süresi } & $0-5 \mathrm{dk}$ & 457 & 46.0 \\
\hline & $5-10 \mathrm{dk}$ & 404 & 40.7 \\
\hline & $10-15 \mathrm{dk}$ & 112 & 11.2 \\
\hline & 15 dk'dan fazla & 21 & 2.1 \\
\hline \multirow{4}{*}{ Durakta Bekleyen Ort. Kişi Sayısı } & $0-5$ kişi & 288 & 29.0 \\
\hline & 5-10 kişi & 520 & 52.3 \\
\hline & 10-15 kişi & 140 & 14.1 \\
\hline & 15 kişiden fazla & 46 & 4.6 \\
\hline \multirow{4}{*}{ Durakta Ortalama Bekleme Süreniz } & $0-5 \mathrm{dk}$ & 87 & 8.7 \\
\hline & $5-10 \mathrm{dk}$ & 425 & 42.7 \\
\hline & $10-15 \mathrm{dk}$ & 342 & 34.4 \\
\hline & $15 \mathrm{dk}$ 'dan fazla & 140 & 14.1 \\
\hline \multirow{3}{*}{ Ortalama Durak Kullanma Sıklığı } & Günlük bazda en az bir kez & 425 & 42.7 \\
\hline & Haftalık bazda en az bir kez & 341 & 34.3 \\
\hline & Aylık bazda en az bir kez & 228 & 22.9 \\
\hline
\end{tabular}

Tablo 1 detaylı olarak incelendiğinde çalışma kapsamında farklı belirleyici özellikteki yolculara ulaşıldığ1 ve farklı kesimlerin görüsslerinin alındığg görülmektedir. Yapılan anket çalışması kapsamında ayrıca, kullanıcıların durak kullanım amacı ve durakta nasıl vakit geçirdikleri hakkında daha detaylı bilgi edinebilmek amaciyla çoklu (birden fazla) seçmeli sorularda yöneltilmiştir. Durak kullanım amacı için elde edilen çoklu seçmeli sorulara ait sonuçlar Tablo 2'de, duraklarda mevcut durumda vakitlerini nasıl değerlendirdiklerini belirlemeye yönelik çoklu seçmeli sorulara ait elde edilen sonuçlar ise Tablo 3 'te özetlenmiştir. Çoklu (birden fazla) seçmeli sorulara göre elde edilen sonuçlardan kapalı duraklarda en öncelikli amacın otobüs beklemek, bu tür duraklarda bekleyenlerin bekleme 
esnasında zaman geçirmek amacıyla en fazla

teknolojik aletlerle ilgilendikleri belirlenmiştir.

Tablo 2. Çoklu seçmeli sorularla elde edilen kapalı durak kullanım amacı

\begin{tabular}{|c|c|c|c|c|c|c|c|}
\hline Cevaplar & $\begin{array}{c}\text { Otobüs } \\
\text { Bekleme }\end{array}$ & $\begin{array}{l}\text { Otomobil } \\
\text { Bekleme }\end{array}$ & $\begin{array}{c}\text { Arkadaş } \\
\text { Bekleme/Buluşma } \\
\end{array}$ & $\begin{array}{c}\text { Soğuktan/Sicaktan } \\
\text { Korunma }\end{array}$ & Dinlenme & Diğer & $\begin{array}{c}\text { Toplam } \\
(\Sigma) \\
\end{array}$ \\
\hline Otobüs Bekleme & 899 & 35 & 50 & 61 & 47 & - & 1092 \\
\hline Otomobil Bekleme & 35 & 28 & - & 2 & - & - & 65 \\
\hline $\begin{array}{c}\text { Arkadaş Bekleme/ } \\
\text { Buluşma }\end{array}$ & 50 & - & 24 & - & - & - & 74 \\
\hline $\begin{array}{c}\text { Soğuktan/ } \\
\text { Sicaktan Korunma }\end{array}$ & 61 & 2 & - & 22 & - & - & 85 \\
\hline Dinlenme & 47 & - & - & - & 13 & - & 60 \\
\hline Diğer & - & - & - & - & - & 11 & 11 \\
\hline Toplam $(\Sigma)$ & 1092 & 65 & 74 & 85 & 60 & 11 & 1387 \\
\hline
\end{tabular}

Tablo 2 incelendiğinde, örneğin durakta otobüs bekleyen 899 kişinin sadece otobüs beklemediği, duraklarda bazen otomobil (35 kişi) bazen arkadaş/bekleme (50 kişi), soğuktan/sıcaktan korunma (61 kişi) ve dinlenme (47 kişi) amaçlarıla da duraklarda bekledikleri görülmektedir. Benzer durum Tablo 3 için de geçerli olup Tablo 3 incelendiğinde kullanıcıların kapalı duraklarda nasıl vakit geçirdikleri üzerine elde edilen bilgiler verilmiştir.

Tablo 3. Çoklu seçmeli sorularla elde edilen kullanıcıların kapalı durakta nasıl vakit geçirdiklerine ait bilgiler

\begin{tabular}{|c|c|c|c|c|c|c|}
\hline Cevaplar & $\begin{array}{c}\text { Teknolojik } \\
\text { aletlerle ilgilenme }\end{array}$ & $\begin{array}{l}\text { Etrafi } \\
\text { Izleme }\end{array}$ & $\begin{array}{c}\text { Duraktakilerle } \\
\text { Sohbet Etme }\end{array}$ & $\begin{array}{c}\text { Kitap Okuma/Ders } \\
\text { Çalışma }\end{array}$ & Diğer & 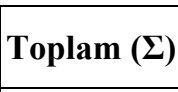 \\
\hline $\begin{array}{c}\text { Teknolojik Aletlerle } \\
\text { İlgilenme }\end{array}$ & 560 & 82 & 29 & 13 & 2 & 686 \\
\hline Etrafi İzleme & 82 & 338 & 2 & - & - & 422 \\
\hline $\begin{array}{l}\text { Duraktakilerle } \\
\text { Sohbet Etme }\end{array}$ & 29 & 2 & 42 & - & - & 73 \\
\hline $\begin{array}{l}\text { Kitap Okuma/ } \\
\text { Ders Çalışma }\end{array}$ & 13 & - & - & 14 & 0 & 28 \\
\hline Diğer & 2 & - & - & - & 11 & 13 \\
\hline Toplam $(\Sigma)$ & 686 & 422 & 73 & 28 & 13 & 1223 \\
\hline
\end{tabular}

\subsection{Duraklar Hakkındaki Görüş ve Önerilerin Gruplandirilmast}

Çalışma kapsamında, kullanıcıların mevcut duraklar hakkındaki düşünce ve beklentilerini ölçmek amaciyla 5'li likert ölçeği ile elde edilen değişkenler kullanılarak (1.Kesinlikle Katılmıyorum, 2. Katılmıorum, 3. Kararsızım, 4. Kat1lyorum, 5. Kesinlikle Kat1lyorum) hazırlanan sorular ile yapılan anket sonucu elde edilen veriler, faktör analizi ile irdelenmiştir. Hazırlanan 22 soru boyut indirgeyerek faktörler yardımıyla açıklanmaya çalışılmış ve elde edilen sonuçlar Tablo 4'te özetlenmiştir. Analizlerde, elde edilen verilerin faktör analizine uygunluğunu belirleyebilmek amaciyla Kaiser-Meyer-Olkin (KMO) değeri incelendiğinde bu değerin 1'e yakın olduğu $(\mathrm{KM} 0=0.839)$ yani verilerin faktör analizi için uygun olduğu sonucuna ulaşılmıştır. Ayrıca Bartlett küresellik testi için test istatistiği $=4911.206$; $P$ değeri $\quad(\mathrm{Sig})=$.0.000 ve varyans açıklama oranı $=0.606$ olarak hesaplanmıştır. $\mathrm{P}<0.01$ olduğundan korelasyon matrisinin birim matrise eşit olduğu yokluk hipotezi reddedilmiş ve Bartlett testine göre de veri setinin faktör analizine uygun olduğu hesaplanmıştır. Yapılan analizler sonucu Türkiye'de kapalı durak kullanıcılarının mevcut duraklar hakkındaki düşünce ve beklentileri faktör yükü 0.40 alınarak 5 faktörlük bir ölçekle açıklanmıştır. Hazırlanan ölçeğin ne kadar güvenilir olduğunu belirlemek amaciyla Cronbach Alpha (Cronbach'Alpha $=0.825)$ katsayısına bakıldığında bu değerin 1'e yakın olduğu yani faktör analizi ile elde edilen ölçeğin güvenilir olduğu sonucuna ulaşılmıştır. Tablo 4 detaylı olarak incelendiğinde faktör analizi ile yapilan gruplandırmaya göre kapalı durak kullanıcıları, mevcut duraklar hakkında olumlu düşüncelere sahip olsalar da kullanıcıların duraklarda olmasını istediği diğer bazı özelliklerin olduğu sonucuna ulaşılmıştır. Analiz sonucuna göre kullanıcıların 
duraklardan; kullanıcıları bilgilendirici, onların beklerken zaman geçirebilmesini sağlayan ve birçok ihtiyaca cevap verecek teknolojik bir altyapıya sahip olmasını istedikleri belirlenmiştir.
Ayrıca bazı kullanıcıların duraklarda kendilerince önemli gördüğü (gazete/kitap olması, yiyecekiçecek otomatı vb.) bazı özelliklerinde olmasını istedikleri görülmüştür.

Tablo 4. Kapalı durak kullanıcılarının mevcut duraklar hakkındaki düşünce ve beklentilerinin gruplandırılmas1

Faktör 1: Mevcut duraklar hakkındaki genel düşünce

(Varyans açıklama oranı: \%17.46, Cronbach' Alpha $=0.847$

F01: Duraklarda 1sitma ve havalandirma sisteminden memnunum.

F02: Durakların görsel tasarımından/estetiğinden memnunum.

F03: Duraklardaki oturaklar konforludur

F04: Duraklarda kapı sensörleri (el) hatasız çalışmaktadır.

F05: Duraklardan memnunum.

F06: Durakların sayısından ve sıklığından memnunum.

F07: Duraklarda kapı açılma-kapanma süreleri yeterlidir.

Faktör 2: Durakların bilgilendirici bir altyapıya sahip olması isteği

(Varyans açıklama oranı: \%14.38, Cronbach' Alpha $=0.815$

F08: Duraktan geçen otobüslerin güzergâh ve sefer saatlerini bilmeliyim

F09: Beklediğim otobüsün kaç dakika veya kaç durak öncesinde olduğunu bilmeliyim

F10: Beklediğim otobüsteki boş koltuk sayısını görebilmeliyim.

F11: Otobüslerin, gideceğim durağa tahmini varış süresini bilmeliyim.

Faktör 3: Durakların birçok ihtiyaca cevap verecek teknolojik bir altyapıya sahip olması isteği

(Varyans açıklama oranı: \%12.54, Cronbach' Alpha $=0.798$

F12: Telefon/Tabletime uygun ücretsiz şarj aleti bulunmalıdır.

F13: Durakta telefon/tablet şarj edebilmek için priz bulunmalıdır.

F14: Ücretsiz internet erişimi olmalıdır.

F15: Beklediğim esnada yaşadığım şehirle ilgili haberler ve güncel gelişmeleri izleyebileceğim dijital ekranlar olmalıdır.

Faktör 4: Durakların kapasitesi hakkındaki genel görüşler

(Varyans açıklama oranı: \%10.29, Cronbach' Alpha $=0.735$

F16: Duraklarda oturmak için boş yer bulabiliyorum.

F17: Duraklarda yoğun saatlerde kapalı alanda yer bulabiliyorum.

F18: Durak içleri yeterli kullanım alanına sahiptir.

Faktör 5: Duraklarda olması beklenilen diğer bazı önemli özellikler

(Varyans açıklama oranı: \%5.95, Cronbach’ Alpha=0.691

F19: Durakta Gazete/kitap vb. olmalıdır.

F20: Durak içerisinde ya da yanında yiyecek içecek otomat makinası olmalıdır.

F21: Duraklar ve durak çevresi yaşl1, engelli ve bebek arabalılar için uygun tasarıma sahip olmalıdır.

F22: Durakta kart satın alabileceğim ya da bakiye yükleyebileceğim elektronik makineler olmalıdır.

\subsection{Kullanucılar ve Durak Memnuniyetleri Arasındaki İlişkinin İncelenmesi}

Çalışma kapsamında kapalı durak kullanıcılarının mevcut duraklardan memnuniyetleri ile kullanıciların belirleyici ve durak kullanım özellikleri arasındaki ilişkiyi incelemek amacıyla Sıralı Logit Regresyon Analizi yapılmıştır. Analizlerde kullanılan bağımlı ve bağımsız değişkenler Tablo 5'te özetlenmiştir. Analiz sonucunda $\mathrm{P}=0.000<0.01$ olduğundan tahmin edilen modelin anlamlı bir model olduğu sonucuna ulaşılmıştır. Modelde tek bir sürekli bağımsız değişken olduğu için rassal bağlantı sorunu olmadığı tespit edilmiştir. Modelde bir spesifikasyon hatasının olup olmadığını incelemek amacıyla link testi yapılmıştır. Elde edilen hatsq (tahmin edilen değerlerin karesi) değişkenine ait katsayı istatistiksel olarak anlamsız olduğundan (katsayl $=0.0996$ ve $\mathrm{P}=0.154>0.10$ ) tahmin edilen modelde herhangi bir model spesifikasyon (eksik ya da yanlış değişken) hatasının olmadığı görülmüştür. Paralel regresyon varsayımını incelemek amaciyla ise Olabilirlik Oran ve Bratt testleri yapılmıştır. Olabilirlik Oran testine ait sonuçlar irdelendiğinde test istatistiği 176.62 ve $\mathrm{P}=0.132$ olarak hesaplanmıştır. $\mathrm{P}=0.132>0.10$ olduğundan odds oranlarının bağımlı değişkenin düzeyleri arasında değişmediğini söyleyen yokluk hipotezi 0.10 yanılma düzeyinde kabul edilmiştir. 
özelliklerin durak memnuniyeti üzerinde istatistiksel olarak anlamlı bir etkisinin olmadığ görülmektedir. Yine yapılan analizlerden Antalya'da kapalı durak kullanma değişkeni katsayıs1 -1.678 olarak hesaplanmıştır ve bu katsayı istatistiksel olarak anlamlıdır. Bu sonuç, Antalya'daki kapalı durak kullanıcılarının Gümüşhane'dekilere göre memnun olma olasılıklarının daha düşük olduğunu göstermektedir. Benzer şekilde meslek değişkenine ait analiz sonuçları incelendiğinde, durak kullanıcılarının mesleklerinin "memur" ve "öğrenci" olması durumunda katsayılar sırasıyla 1.382 ve -0.668 olarak hesaplanmıştır. $\mathrm{Bu}$ katsayılar negatif ve istatistiksel olarak anlamlidirlar $(\mathrm{P}<0.01)$. Bu durum memur ve öğrencilerin duraklardan memnun olma olasılıklarının hiç çalışmayan kullanıcılara göre daha düşük olduğunu göstermektedir. Ayrıca yapılan analizlerden işçilerin ve serbest mesleğe sahip olan kullanıcılara ait katsayıların istatistiksel olarak anlamsız olduğu $(\mathrm{P}>0.1)$ ve dolayısıyla kullanıcıların bu mesleklere sahip olmalarının durak memnuniyeti üzerinde istatistiksel olarak anlamlı bir etkisinin olmadığı belirlenmiştir. Kullanıcıların durakta bekleme süresi değişkeni incelendiğinde ise durakta 5-10 dk. arasinda bekleme süresine ait katsayının istatistiksel olarak anlamsız olduğu yani durak memnuniyeti üzerinde istatistiksel olarak anlamlı bir etkisinin olmadığ 1 belirlenmiştir. Durakta bekleyen kişi sayıs1 incelendiğinde ise, durakta bulunan kişi sayısı değişkenlerinin katsayılarının negatif ve istatistiksel olarak anlamlı olduğu hesaplanmıştır $(\mathrm{p}<0.01) . \mathrm{Bu}$ sonuç, durakta bekleyen kişi sayısının artmasının kullanıcıların, duraklardan memnun olma olasılıklarının durakta ortalama kişi sayısının 0-5 kişi arasında olması durumuna göre daha düşük olduğunu göstermiştir. Durakta ortalama bekleme süresinin artmas1 yani 10 dk.'dan daha fazla olmasına ait değişkenlerin katsayılarını negatif ve istatistiksel olarak anlamlı olduğu hesaplanmıştır $(\mathrm{P}<0.05) . \quad \mathrm{Bu}$ durumda durakta ortalama bekleme süresi 10 dk.'dan fazla olan kullanıcıların duraklardan memnun olma olasiliklarının 0-5 dk. bekleyenlere göre daha düşük olduğunu ortaya koymuştur.

Her bir değişken için oransal odds oranları incelendiğinde ise kapalı durak kullanıcılarının yaşadığı şehir, meslek grubunun memur ve öğrenci olmasının, durakta bekleyen kişi sayısının ve durakta bekleme süresinin 10 'dk ve daha fazla olmasina ait oranların istatistiksel olarak anlamlı olduğu hesaplanmıştır. Sonuçlar incelendiğinde, Antalya'da yaşayan kapalı durak kullanıcıları için odds oranı 0.186 olarak hesaplanmıştır. Bu sonuca göre, Antalya'da yaşayanların daha üst bir memnuniyette olma olasıllğı Gümüşhane'de yaşayanların \%18.6's1 kadardır. Örneğin, Antalya'da yaşayan ve "Kapalı duraklardan çok memnunum" şeklinde cevap veren bir kullanıcının Antalya'daki duraklardan memnun olarak kalma olasılığ1 Gümüşhane'deki kullanıcıların \%18.6's1 kadardır. Benzer şekilde meslek grubunun memur ve öğrenci olması durumunda çalışmayan durak kullanıcılarına göre duraklardan memnun kalma olasılığı çalışmayan kullanıcılara göre daha azdır. Durakta bekleyen kişi sayısına göre durum incelendiğinde ise durakta ortalama bekleyen kişi sayısının 5 ve 5 'ten büyük olması durumunda kullanıcıların duraklardan memnun kalma olasılığ durakta bekleyen kişi sayısının ortalama 5 kişiden az olması durumuna göre daha azdır. Kullanıcıların durakta ortalama bekleme süresine göre durum incelendiğinde ise durakta ortalama bekleme süresinin $10 \mathrm{dk}$.'dan fazla olmas1 durumunda kullanıcıların duraklardan memnun kalma olasılığı durakta ortalama bekleme süresi 0$5 \mathrm{dk}$. arasında olanlara göre daha az olması beklenmektedir.

Sıralı Logit Regresyon ile ayrıca tahmin edilen olasılıklardaki değişimler marjinal etkiler olarak hesaplanmıştır. Yani bağımsız değişkendeki bir birimlik artışın tahmin edilen olasılık üzerindeki etkisi incelenmiştir. Kapalı durak kullanıcılarının yaşadığı şehir, meslek grubunun memur ve ögrenci olması, durakta bekleyen kişi sayısının ve durakta bekleme süresinin $10^{\prime} \mathrm{dk}$ ve daha fazla olmasına ait marjinal etkiler için katsayılar istatistiksel olarak anlamlı bulunmuştur. Örneğin Antalya'da yaşayan kapalı durak kullanıcıları için marjinal etki katsayısı -0.028 olarak hesaplanmıştır. Bu sonuca göre, Antalya'da durak kullanıcısı olma durumundaki bir birimlik artış, mevcut duraklardan çok memnun olma olasilıklarını -0.028 birim azaltmaktadır. Benzer şekilde meslek grubunun memur ve öğrenci olmasındaki bir birimlik artış, mevcut duraklardan çok memnun olma olasılıklarını, katsayılarının negatif olmasından dolayı azalacaktır. Durakta bekleyen ortalama kişi sayısı ve bekleme süresine göre durum incelendiğinde ise durakta ortalama bekleyen kişi sayısının 5 ve 5'ten büyük olması ve durakta ortalama bekleme süresinin $10 \mathrm{dk}$.'dan fazla olması durumlarımdaki bir birimlik artış yine duraklardan çok memnun olma olasılıklarını, katsayıların negatif olmasından dolayı azaltması beklenmektedir.

\section{Tartışma ve Sonuçlar}

Son y1llarda artan araç ve nüfusa bağlı olarak toplu taşıma kullanıcılarının dikkat çektiği en 
önemli sorunların başında duraklara erişim ve durakların kötü fiziksel koşullara sahip olması gelmektedir. Belirtilen bu soruna çözüm bulabilmek ve toplu taşıma kullanımını daha da yaygınlaştırmak amacıyla topluma taşıma yetkilileri çok sayıda konforlu ve akıllı duraklar inşa etmekte ve kullanıcılara daha iyi koşullarda durakta bekleme olanağı sunmaya çalışmaktadır. Ülkemizdeki açık ve kapalı duraklar incelendiğinde, açık durak tasarımlarının geometrik ve belirleyici özelliklerinin birbirine oldukça benzediği görülmüştür. Yapılan bu gözlemler sonucu elde edilen bilgilere göre açık durak tasarımı konusunda ülkemizde kullanımı yaygın bir tasarımın olmasının etkili olduğu söylenebilmektedir. Ülkemiz şehirlerindeki kapalı duraklar incelendiğinde ise her ne kadar ayn amaç için inşa edilmiş olsalar da geometrik ve belirleyici özelliklerinin birbirinden farklı olduğu görülmüştür. $\mathrm{Bu}$ durum üzerinde, toplu taşıma sistemlerinin önemli bir parçası olan bu kapalı durakların, inşa edildiği şehrin belirleyici özelliklerine ve kullanıcıların beklentilerine göre değişiklik göstermesi oldukça etkilidir. Bu yüzden ülke genelinde tek bir kapalı durak tipi belirleyerek onu ihtiyaç duyulan şehirlerde uygulamak amaciyla ortak bir kapalı durak tasarımının oluşturulması ihtiyaç olan tüm şehirlerde durakların kalitesi konusunda bir birlikteliği sağlayabilmek açısından oldukça önemlidir.

Çalışma kapsamında mevcut kapalı durak kullanıcılarının, farklı hava koşullarına sahip, büyük ve küçük ölçekli şehirlerdeki mevcut kapalı duraklardan memnuniyetleri ile kapalı duraklarda olmasını bekledikleri özellikler incelenmiştir. Elde edilen bulgulara göre durak kullanıcılarının, kapalı duraklarda en öncelikli amaçlarının otobüs beklemek olduğu ve bekleme esnasinda zaman geçirmek amaciyla en fazla teknolojik aletlerle ilgilendikleri belirlenmiştir. Hazırlanan ölçek sorularının faktör analizi ile gruplandırılması ile elde edilen sonuçlara göre ise kullanıcıların; durakların kullanıcıları bilgilendirici, onların beklerken zaman geçirebilmesini sağlayan ve birçok ihtiyaca cevap verecek teknolojik ve fiziksel bir altyapıya sahip olmasını istedikleri belirlenmiştir. Ayrıca bazı kullanıcıların duraklarda kendilerince önemli gördükleri (gazete/kitap olması, yiyecek-içecek otomatı vb.) bazı özelliklerinde olmasını istedikleri tespit edilmiştir. Kullanıcıların mevcut duraklardan memnuniyetleri ile kullanıcıların belirleyici ve durak kullanım özellikleri arasındaki ilişkiyi incelemek amaciyla yapılan Siralı Logit Regresyon analizi sonuçlarına göre ise cinsiyet, eğitim durumu, gelir düzeyi, durağa erişim süresi ve yaş değişkenlerinin durak memnuniyeti üzerinde istatistiksel olarak anlamlı bir etkisinin olmadığı belirlenmiştir. Kapalı durak kullanıcılarının yaşadığ 1 şehir, meslek grubunun memur ve öğrenci olmasının, durakta bekleyen kişi sayısının ve durakta bekleme süresinin $10^{\prime} \mathrm{dk}$ ve daha fazla olmasinın durak memnuniyeti üzerinde istatistiksel olarak anlamlı değişkenler olduğu belirlenmiştir. Yapılan analizlerden kullanıcıların duraklardan beklentilerinin büyük farklılık göstermediği ve kullanıcılarının büyük bir kısmının özellikle durakların akı1lı durak olması görüşünde ortak bir talebe sahip oldukları belirlenmiştir. Yine elde edilen sonuçlara göre kapalı durak kullanıcıları mevcut duraklardan memnun gibi görünse de yine de bu tür duraklarda olmasını bekledikleri bazı özelliklerin olduğu görülmüştür. Ülkemizde ihtiyaç olan tüm kapalı otobüs duraklarının aynı hizmet kalitesine sahip olmasının sağlanmasının kullanıcıların memnuniyeti ve toplu taşıma kullanımı konusunda, oldukça önemli olduğu bilinen bir durumdur. $\mathrm{Bu}$ amaçla çalışma kapsamında elde edilen anlamlı değişkenler göz önüne alınarak tasarlanan ortak bir kapalı durak modelinin oluşturulmasının; şehirlerde çok sık kullanılan durakların kalitesi konusunda katkı sağlayacağ düşünülmektedir.

\section{Teşekkür}

Çalışmaya olan değerli katkılarından dolayı yazarlar İnş. Müh. İsmail Furkan ÇOLAKOĞLU'na teşekkür ederler.

\section{Kaynaklar}

Akbaş, A. ve Akdoğan, E., 2001. İstanbul Kent İçi Trafik Kontrol Sistemi Üzerine Bir Durum Değerlendirmesi, İstanbul'da Kent İçi Ulaşım Sempozyumu, 28-30 Haziran, İstanbul, Türkiye, 28-30.

Ali, A.N., 2010. An Assessment of the Quality of IntraUrban Bus Services in the City of Enugu, Enugu State, Nigeria. Theoretical and Empirical Researches in Urban Management, 6(15), 7491.

Ali, A.N., 2014. Assessment of Passenger Satisfaction with Intra-City Public Bus Transport Services in Abuja, Nigeria. Journal of Public Transportation, 17(1), 91-119.

Aydın, M.M. ve Yıldırım, M.S., 2018. Bisiklet Paylaşım Sistemlerindeki Yolculuk Uzunluğu Üzerinde Etkili Parametrelerin İncelenmesi. Gümüşhane Üniversitesi Fen Bilimleri Enstitüsü Dergisi, 9(1), 163-172. 
Bordagaray, M., dell’Olio, L., Ibeas, A. ve Cecín, P., 2014. Modelling User Perception of Bus Transit Quality Considering User and Service Heterogeneity. Transportmetrica, 2014(10), 705-721.

Eboli, L. ve Mazzulla, G.A., 2009. A New Customer Satisfaction Index for Evaluating Transit Service Quality. Journal of Public Transportation, 12(3), 21-37.

Fellesson, M. ve Friman, M., 2008. Perceived Satisfaction with Public Transport Service in Nine European Cities. Journal of the Transportation Research Forum, 47(3), 93-103.

Hickman, R., Ashiru, O. ve Banister D., 2010. Transport and Climate Change: Simulating the Options for Carbon Reduction in London. Transport Policy, 17(2), 110-125.

Ilıcalı, M., Camkesen, N. ve Kızıltaş, M., 2011. Kent içi Toplu Taşımada Verimliliğin Artırılması, 2.Toplu Taşıma Haftası 4.Ulaşım Sempozyumu ve Sergisi (TRANSIST 2011), 1-2 Aralı, İstanbul, Türkiye, 1-2.

Kamaruddin, R., Osman, I. ve Pei, C.A.C., 2012. Public Transport Services in Klang Valley: Customer Expectations and its Relationship Using SEM. Procedia -Social and Behavioral Sciences, 36, 431-38.

Kaplan, H., 2010. Kentiçi Toplu Taşımada Durak Erişilebilirliği, Ulusal Toplu Ulaşım Sempozyumu ve Sergisi (TRANSIST 2010), 13 Aralık, İstanbul, Türkiye, 131-144.

Kim, S., Ulfarsson, G.F. ve Hennessy, J.T., 2007. Analysis of Light Rail Rider Travel Behavior: Impacts of Individual, Built Environment and Crime Characteristics on Transit Access. Transportation Research Part A: Policy and Practice, 41(6), 511-522.

Murat, Y.S. ve Cakici, Z., 2017. Comparative Analysis of Public Transport Users' Perception Targeting Sustainable Transportation, in: Hermann Knoflacher, H. and Ocalir-Akunal E.V., (Eds.), Engineering Tools and Solutions for Sustainable Transportation Planning, IGI Global Publishing, Pennsylvania, USA, 4, 76-98.

Murat, Y.S. ve Demirkollu, M., 2017. Determination of an Ideal Frequency of Daily Bus Trips with Goal Programming Method. First International Turkish World Engineering and Science Congress, 7-10 December, Antalya, Turkey, 1820.

Murat, Y.Ş., Kutluhan, S. ve Uludağ, N., 2014. Use of Fuzzy Optimization and Linear Goal Programming Approaches in Urban Bus Lines
Organization, Soft Computing in Industrial Applications. Springer, 223, 277-287.

Nehir, Y., 2009. İzmir'de Otobüs Duraklarının Etkin Kullanımları Üzerine Bir İnceleme, Yüksek Lisans Tezi, Fen Bilimleri Enstitüsü Dokuz Eylül Üniversitesi, İzmir, 180s.

Oña, J.D., Oña, R.D. ve López, G., 2016. Transit Service Quality Analysis Using Cluster Analysis and Decision Trees: A Step Forward to Personalized Marketing in Public Transportation. Transportation, 43, 725-747.

Saplığlu, M. ve Aydın, M.M., 2018. Choosing Safe and Suitable Bicycle Routes To Integrate Cycling and Public Transport Systems. Journal of Transport \& Health, 10, 236-252.

Shaaban, K. ve Khalil, R.F., 2013. Investigating the Customer Satisfaction of the Bus Service in Qatar. Procedia-Social and Behavioral Sciences, 104(2), 865-874.

Tekin, S., Köfteci, S., Aydın, M.M. ve Yildirim, M.S., 2018. Trip Optımızation for Public Transportation Systems with Linear Goal Programming (LGP) Method. Sigma: Journal of Engineering \& Natural Sciences, 36(4), 921933.

Türkiye İstatistik Kurumu, 2018. 2018 Y1lı Nüfus İstatistikleri, Ankara, Türkiye.

Tyrinopoulos, Y. ve Constantinos A., 2008. Public Transit User Satisfaction: Variability and Policy Implications. Transport Policy, 15(4), 260-272.

United Nations (UN), 2014. World's Population Increasingly Urban with More than Half Living in Urban Areas, http://www.un.org/en/ development/desa/news/population/worldurbanization-prospects-2014.html.

URL-1, http://www.un.org/en/development/desa/news/ population/world-urbanization-prospects2014.html. 5 Mayıs 2019.

Weng, J., Di, X., Wang, C., Wang, J. ve Mao, L., 2018. A Bus Service Evaluation Method From Passenger's Perspective Based on Satisfaction Surveys: A Case Study of Beijing, China. Sustainability, 10(8), 2723-2738.

Wojuade, C.A. ve Badiora, A.I., 2017. Users Satisfaction with Public Transport Operations in Ibadan, Nigeria. The Journal of Social Sciences Research, 3(9), 88-96.

Yaşar, A.B., 2009. Kentiçi Otobüs Taşımacılığında Talep Tahmini. Yüksek Lisans Tezi, Fen Bilimler Enstitüsü Pamukkale Üniversitesi, Denizli, 82s. 